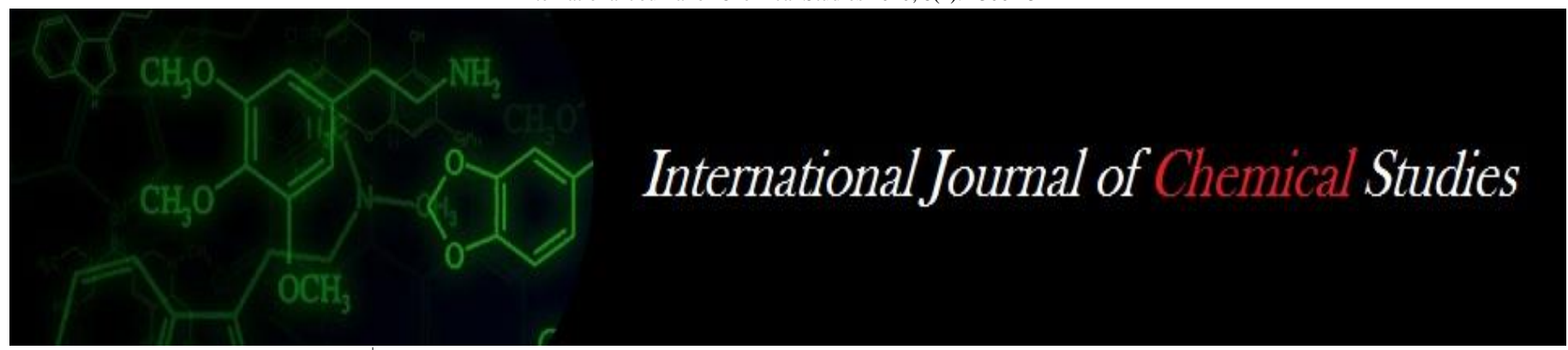

P-ISSN: 2349-8528

E-ISSN: 2321-4902

www.chemijournal.com

IJCS 2020; 8(2): 1306-1311

(C) 2020 IJCS

Received: 16-01-2020

Accepted: 20-02-2020

Urvashi Ramnikbhai Popalia Amul Fed Dairy, Gandhinagar, Gujarat, India

Patel Amitkumar Manojbhai SMC College of Dairy Science, AAU, Anand, Gujarat, India

Smitha Balakrishnan SMC College of Dairy Science, AAU, Anand, Gujarat, India

Chaudhari Bhoomiben Bharatbhai

Amul Dairy, KDCMPU Ltd.,

Anand, Gujarat, India
Corresponding Author:

Patel Amitkumar Manojbhai

SMC College of Dairy Science,

AAU, Anand, Gujarat, India

\section{Functional, sensory, physico-chemical and microbial changes in oats and milk protein concentrate based malted milk food during storage}

\author{
Urvashi Ramnikbhai Popalia, Patel Amitkumar Manojbhai, Smitha \\ Balakrishnan and Chaudhari Bhoomiben Bharatbhai
}

DOI: https://doi.org/10.22271/chemi.2020.v8.i2t.8946

\begin{abstract}
Malted milk food is one of very attractive options owing to their health benefits and economic considerations. There exists a definite commercial potential for a newer malted milk food comprising healthful ingredients such as oats and milk protein concentrate. The oats and milk protein concentrate based malted milk were evaluated for its shelf life at $37 \pm 2{ }^{\circ} \mathrm{C}$ after packing in laminates of metallized PET-Polyester/Polyfilm pouches at 15-days interval. Powder density and solubility index increased, while flowability decreased for control and experimental samples at the end of 180 days. The score of the sensory characteristics for the product decreased throughout the storage period. Moisture content, water activity, free fatty acids, total HMF content, and TBA value (OD at 532nm) of control and experimental sample increased throughout the storage period. The standard plate count of both the samples decreased with increase in storage period.
\end{abstract}

Keywords: Milk protein concentrate, malted milk food, oats, vacuum tray drying

\section{Introduction}

Milk-cereal composites based cuisines are widely growing in India and worldwide. Technically, these products are categorized into malted milk foods, complementary foods, weaning foods, traditional dairy products, breakfast cereals, porridge, etc. Amongst all cereals, oats contain the largest quantities of protein and fat. The protein quality compares favourably with the protein of other cereal grains, and the fat has a favourable ratio of polyunsaturated to saturated fats. Oats has ample carbohydrates of high digestibility, except for the fibre component, which however has desirable physiological properties. Oat bran and germ are rich in vitamins and minerals (Lockhart and Hurt, 1986) ${ }^{[4]}$. Oats is also a significant source of antioxidants like tocotrienol and lignan precursors for formation of mammalian lignans by friendly intestine bacteria (Potty, 2006) ${ }^{[6]}$. The American Dairy Products Institute and the U.S. Dairy Export Council, filed a Generally Recognized as Safe (GRAS) notification for milk protein concentrate (MPC) and milk protein isolate (MPI) in 2012 for use as food ingredients for functional or nutritional purposes in multiple food applications except infant formula (GRAS Notice No. GRN000504). MPCs are ideal ingredients for a wide range of applications, due to their concentrated source of protein, excellent functionality, and clean dairy flavour. MPCs are multifunctional ingredients and provide benefits, such as water binding, gelling, foaming, emulsification, and heat stability (Agarwal et al., 2015) ${ }^{[1]}$. India is the world's biggest market for malt- milk based food products. Malted milk foods provide high nutritional value with necessary levels of minerals and vitamins. It also fulfils requirement of consumers as a milk substitute in milk deficient area and people who can't digest pure milk. In addition, manufacture of malted milk food provides value addition to milk based products. These foods are valued for their nutrition, easy digestibility, high palatability and convenience of consumption. Malt based food products provide better operating margin in comparison with conventional dairy products. These types of health foods could be a good carrier for fortification. The present study was conceptualized to access the functional, sensory, physicochemical and microbial changes in oats and milk protein concentrate based malted milk food during storage. 


\section{Materials and Method \\ Raw Materials}

Barley malt was procured from The Malt Company (India) Limited, Gurgaon. Malt extract was procured from J.K. Malt Products Pvt. Ltd, Nadiad, Gujarat. Milk protein concentrate85 (MPC-85) containing 85\% protein was procured from Anshul Life Sciences, Goregaon (East), Mumbai. Oats (Kosh brand) was brought from the authorized dealer of Anand town. White butter was obtained from Vidya Dairy, Anand. Fine crystalline sugar of Madhur brand was used. Cocoa powder of Cadbury brand was used as colour and flavour compound.

\section{Equipment/Instruments}

The equipment and instruments used in the present study are detailed below:

Bulk density meter (Thermonik brand Bulk Density Tester, Mumbai, India); Centrifuge (Remi: Model No. R-24, CX2804, Mumbai, India); Hobart mixer (M/s. Hobart, Corporation, Canada); Spectrophotometer (Labline Technologies Pvt. Ltd., India); Vacuum tray dryer (Perfect Engineering and Allied Works Pvt. Ltd., Baroda, India); Water activity meter (Hygrolab 3, Rotronic Measurement Solutions AG, Switzerland); Hot air oven (Model No. IK-III, IKON, India); Analytical balance (Sartorius, England), Vortex mixture (SAIF Surgical \& Scientific Equipment, Gujarat).

\section{Glasswares}

All glasswares used in the study were of standard quality supplied by authorized dealers. In case of specific experiments, the calibrated glasswares as specified by Bureau of Indian Standards (BIS, 1981) were used.

\section{Chemicals}

All the chemicals used in the preparation of different reagents were of analytical grade (AR) and were procured from standard companies. The reagents required for analysis were freshly prepared adopting standard procedures.

\section{Packaging Materials}

The product after drying was packed in laminates of Metallised Polyethylene Terephthalate (METPET)-Polyester/ Polyfilm pouches of $85 \mu \mathrm{m}$ thickness and the packets were stored at $37 \pm 2{ }^{\circ} \mathrm{C}$.

\section{Manufacture of Oat and Milk Protein Concentrate (MPC) based Malted Milk Food}

Oat flour and barley malt in the ratio of 40:60 was soaked in four times water of the total grist mixture. The grist mixture was then allowed to mash at $45-68{ }^{\circ} \mathrm{C}$ for $3 \mathrm{~h}$. The mixture was then heated to $80{ }^{\circ} \mathrm{C}$ for 10 minutes to inactive the enzymes. After the mashing process, spent grains were filtered. Based on preliminary trials, total concentrate mix (100g) consisted of malt solids, milk solids (MPC-85 and white butter), sugar and cocoa powder. Proportion of sugar and cocoa powder was kept constant at 20 per cent and 5 per cent respectively of total concentrate mix. Optimized wort was mixed with malt extract (ME) so as to achieve 50 per cent total solids. Concentrate mix was spread in greased trays which was then dried at $45 \pm 5{ }^{\circ} \mathrm{C}$ in vacuum tray dryer at the vacuum of $650 \mathrm{~mm}$ of $\mathrm{Hg}$ for $4-5 \mathrm{~h}$. Control product preparation involved use of wheat flour as an adjunct with barely malt in 60:40 ratio for wort production. Other ingredients were kept constant as in case of manufacture of experimental sample.

\section{Results and Discussion}

The oat and milk protein concentrate based malted milk food (T2) and control sample (T1) were stored at room temperature $\left(37 \pm 2{ }^{\circ} \mathrm{C}\right)$ after packing them in laminates of metallized PET Polyester/Poly film pouches $(85 \mu \mathrm{m}$ thickness). The samples were analysed for changes in functional properties, sensory attributes, physico-chemical characteristics as well as microbial changes at 15-days interval for a period of six months.

\section{Changes in the Functional Properties of Oat and Milk Protein Concentrate Based Malted Milk Food during Storage}

The changes in functional properties of samples T1 and T2 packed in MET PET and stored at room temperature $(37 \pm 2$ ${ }^{\circ} \mathrm{C}$ ) is shown in the Table 1 . Poured density of T1 and T2 increased from 0.483 and $0.356 \mathrm{~g} / \mathrm{cm}^{3}$ to 0.625 and 0.416 $\mathrm{g} / \mathrm{cm}^{3}$ respectively at the end of 180 days. Same trend was observed in other densities like loose density of $T_{1}$ and $T_{2}$ increased from 0.649 and $0.455 \mathrm{~g} / \mathrm{cm}^{3}$ to 0.780 and 0.493 $\mathrm{g} / \mathrm{cm}^{3}$, powder density of $\mathrm{T}_{1}$ and $\mathrm{T}_{2}$ increased from 0.720 and $0.537 \mathrm{~g} / \mathrm{cm}^{3}$ to 0.781 and $0.589 \mathrm{~g} / \mathrm{cm}^{3}$ and particle density of $\mathrm{T}_{1}$ and $\mathrm{T}_{2}$ increased from 1.20 and $1.25 \mathrm{~g} / \mathrm{cm}^{3}$ to 1.23 and $1.36 \mathrm{~g} / \mathrm{cm}^{3}$ respectively. Flow ability of $\mathrm{T} 1$ and $\mathrm{T} 2$ decreased (i.e. increased in measured time) from 68.20 and $81.10 \mathrm{~s}$ to 79.76 and $89.75 \mathrm{~s}$ respectively at the end of 180 days. Solubility index of T1 and T2 increased from 1.19 and 13.63 $\mathrm{ml}$ to 3.60 and $15.35 \mathrm{ml}$ respectively at the end of 180 days of storage at $37 \pm 2{ }^{\circ} \mathrm{C}$. The changes in the poured density, loose density, powder density, particle density, flow ability and solubility index of the treatments (T1 and T2) and interaction effect between the treatments and periods were significant $(p<0.05)$.

Kumar (1983) ${ }^{[3]}$ reported decrease in bulk density from initial value of 0.67 to $0.43 \mathrm{~g} / \mathrm{cm}^{3}$. Same effect was reported by Modha (2016) ${ }^{[5]}$ for ready-to-reconstitute kheer mix in which bulk density decreased from 0.743 to $0.686 \mathrm{~g} / \mathrm{cm}^{3}$ during storage period of 6 months at $37^{\circ} \mathrm{C}$.

Salooja (1983) ${ }^{[7]}$ reported increase in angle of repose from 62.93 to $66.16,65.74,65.53,65.30,65.07$ and 64.34 respectively for the powder packed in LDPE, METP, PP/LDPE/METP/LDPE, PP/AL/LDPE, glass jar and tin can during storage up to 12 months at $30{ }^{\circ} \mathrm{C}$.

Banerjee and Ladkani (1985) [2] observed decrease in flowability (Contingent of angle of repose) of malted milk powder packed in glass bottles as well as in polyfilm pouches up to three months from initial value of 0.74 to 0.66 and 0.62 , respectively.

Modha (2016) ${ }^{[5]}$ observed that flowability (sec) of ready-toreconstitute kheer mix packed in laminates of metallized petpolyester/polyfilm increased from 122.3 to $234.3 \mathrm{~s}$ at the end of storage period of 6 months $37^{\circ} \mathrm{C}$.

Salooja (1983) ${ }^{[7]}$ reported increase in solubility index (ml) from 2.77 to $7.70,6.93,6.63,6.30,5.90$ and $5.77 \mathrm{ml}$ respectively for the powder packed in LDPE, METP, PP/LDPE/METP/LDPE, PP/AL/LDPE, glass jar and tin can during storage up to 12 months at $30{ }^{\circ} \mathrm{C}$.

Banerjee and Ladkani (1985) [2] observed increase in solubility index $(\mathrm{ml})$ of malted milk powder packed in glass bottles as well as in polyfilm pouches up to three months from initial value of 0.57 to 1.83 and $1.87 \mathrm{ml}$ respectively. 
Kumar (1983) ${ }^{[3]}$ reported increase in solubility index during storage period up to 12 months for the chocolate powder made from buffalo milk when packed in PE bags and stored at $37{ }^{\circ} \mathrm{C}$.

Modha (2016) ${ }^{[5]}$ observed that solubility index of ready-toreconstitute kheer mix packed in laminates of metallized petpolyester/polyfilm increased from 2.13 to $8.37 \mathrm{ml}$ at the end of storage period of 6 months at $37^{\circ} \mathrm{C}$.

\section{Changes in the Sensory Characteristics of Oat and Milk Protein Concentrate Based Malted Milk Food during Storage}

The score of the sensory characteristics like flavour, appearance of dry and reconstituted product and colour decreased throughout the storage period (Table 2). The flavour score of $\mathrm{T}_{1}$ and $\mathrm{T}_{2}$ decreased from 8.41 and 8.68 to 5.66 and 6.37 respectively at the end of 180 days. The appearance score of dry product of $\mathrm{T}_{1}$ and $\mathrm{T}_{2}$ decreased from 8.08 and 8.52 to 5.64 and 6.73 respectively at the end of 180 days. Same trend was observed for appearance score of reconstituted product in which score of $\mathrm{T}_{1}$ and $\mathrm{T}_{2}$ decreased from 7.93 and 8.29 to 5.36 and 6.56 , respectively. The colour score of $\mathrm{T}_{1}$ and $\mathrm{T}_{2}$ decreased from 8.08 and 8.58 to 6.510 and 6.78 respectively at the end of 180 days of storage at $37 \pm 2^{\circ} \mathrm{C}$. The changes in the flavour, appearance of dry and reconstituted product an colour scores of the treatments $\left(\mathrm{T}_{1}\right.$ and $\mathrm{T}_{2}$ ) and interaction effect between the treatments and periods were significant $(p<0.05)$. Based on sensory evaluation it was concluded that $T_{2}$ packaged in laminates of metallized PET-Polyester/Polyfilm pouches was acceptable up to 180 days of storage at $37 \pm 2{ }^{\circ} \mathrm{C}$.

Salooja (1983) ${ }^{[7]}$ reported decrease in sensory score during storage of spray dried malted milk powder samples in metallized polyester pouches stored at $30{ }^{\circ} \mathrm{C}$. It was found that flavour score (out of 65) of fresh sample was 61.67, which decreased to 49.00 at the end of 12 months. Same trend was observed in appearance (out of 30) and colour (out of 5) score which decreased from 26.96 and 4.37 to 19.08 and 2.56 respectively.

Kumar (1983) ${ }^{[3]}$ reported that sensory attributes of chocolate powder samples made from buffalo milk and packed in polyethylene bags at $37{ }^{\circ} \mathrm{C}$ during storage period of 12 months. There was significant decrease in overall acceptability from 8.4 to 3.8 .

Banerjee and Ladkani (1985) ${ }^{[2]}$ observed sensory parameters of spray dried malted milk powder packed in polyfilm pouches during storage of 3 months. As per data reported, colour score of fresh sample decreased from 7.2 to 6.30. Other attributes like body and texture, aroma and taste and overall acceptability score of fresh sample decreased from $7.38,7.86$ and 7.12 to $6.64,6.67$ and 6.79 at the end of storage, respectively.

Modha (2016) ${ }^{[5]}$ analysed the sensory attributes of ready-toreconstitute kheer mix packed in laminates of metallized petpolyester/polyfilm pouches during storage period of 6 months at $37{ }^{\circ} \mathrm{C}$. It was found that flavour (out of 45), consistency (out of 35) and colour and appearance (out of 15) score of fresh sample decreased from 42.64, 32.59 and 13.87 to 26.55 , 30.57 and 10.26, respectively.

Changes in the Physico-Chemical Properties of Oat and Milk Protein Concentrate Based Malted Milk Food during Storage

Moisture content of $T_{1}$ and $T_{2}$ increased from 2.88 and 2.10 per cent to 4.35 and 4.03 per cent respectively at the end of
180 days (Table 3 ). Water activity of $T_{1}$ and $T_{2}$ increased from 0.285 and 0.292 to 0.306 and 0.316 respectively at the end of 180 days. Free fatty acids (FFA) content of $\mathrm{T}_{1}$ and $\mathrm{T}_{2}$ increased from 0.17 and 0.22 per cent to 1.92 and 1.18 per cent respectively at the end of 180 days. Total HMF content of $\mathrm{T}_{1}$ and $\mathrm{T}_{2}$ increased from 49.57 and $81.60 \mu$ moles $/ 100 \mathrm{~g}$ to 294.29 and $403.15 \mu$ moles $/ 100 \mathrm{~g}$ respectively at the end of 180 days. TBA value (OD at $532 \mathrm{~nm}$ ) of $\mathrm{T}_{1}$ and $\mathrm{T}_{2}$ increased from 0.95 and 1.18 to 2.29 and 1.87 respectively at the end of 180 days of storage at $37 \pm 2{ }^{\circ} \mathrm{C}$. The changes in the moisture, water activity, FFA content, total HMF and TBA value of the treatments $\left(T_{1}\right.$ and $\left.T_{2}\right)$ and interaction effect between the treatments and periods were significant $(p<0.05)$.

Salooja (1983) ${ }^{[7]}$ reported that moisture per cent increased from 2.93 to $3.95,3.74,3.63,3.44,3.28$ and 3.23 respectively for the powder packed in LDPE, METP, PP/LDPE/METP/LDPE, PP/AL/LDPE, glass jar and tin can during storage up to 12 months at $30{ }^{\circ} \mathrm{C}$.

Kumar (1983) ${ }^{[3]}$ reported increase in moisture content of fresh sample of chocolate powder made from buffalo milk packed in polyethylene bags from 2.41 to 5.00 during the storage period of 12 months at $37^{\circ} \mathrm{C}$.

Banerjee and Ladkani (1985) ${ }^{[2]}$ observed increase in moisture content of malted milk powder packed in glass bottles as well as in polyfilm pouches up to three months from initial value of 3.64 per cent to 3.66 and 3.75 per cent respectively.

Shah et al. (1987) ${ }^{[8]}$ reported increase in moisture content of spray dried acidophilus malted milk powder packed in different packaging material namely PE-aluminium foil laminate, PE bags and metallized polypaper pouches at ambient temperature $\left(28-31{ }^{\circ} \mathrm{C}\right)$ from initial average value of 2.68 per cent to $3.12,6.59$ and 3.61 per cent, respectively.

Modha (2016) ${ }^{[5]}$ reported increase in moisture content of ready-to-reconstitute kheer mix packed in laminates of metallized pet-polyester/polyfilm pouches from 1.84 to 3.41 per cent at the end of storage of 6 months at $37{ }^{\circ} \mathrm{C}$.

Modha (2016) ${ }^{[5]}$ reported decrease in water activity of fresh sample of ready-to-reconstitute kheer mix packed in laminates of metallized pet-polyester/polyfilm pouches from 0.333 to 0.325 at the end of storage of 6 months at $37^{\circ} \mathrm{C}$.

Salooja (1983) ${ }^{[7]}$ reported an increase in free fat content (on fat basis) from 2.58 to $3.91,3.43,3.21,3.26,2.94$ and 2.88 per cent respectively for the powder packed in LDPE, METP, PP/LDPE/METP/LDPE, PP/AL/LDPE, glass jar and tin can during storage up to 12 months at $30{ }^{\circ} \mathrm{C}$.

Kumar (1983) ${ }^{[3]}$ reported increase in free fat content of fresh sample of chocolate powder made from buffalo milk packed in polyethylene bags from 5.33 to 8.08 per cent during the storage period of 12 months at $30{ }^{\circ} \mathrm{C}$.

Modha (2016) ${ }^{[5]}$ reported increase in free fatty acid (\% oleic acid) content of ready-to-reconstitute kheer mix packed in laminates of metallized pet-polyester/polyfilm pouches from 0.09 to 0.19 per cent at the end of storage of 6 months at 37 ${ }^{\circ} \mathrm{C}$.

Salooja (1983) ${ }^{[7]}$ reported increase in total HMF content from 20.27 to $30.48,29.31,28.44,26.98,26.10$ and $25.52 \mu$ moles $/ 100 \mathrm{~g}$ respectively for the powder packed in LDPE, METP, PP/LDPE/METP/LDPE, PP/AL/LDPE, glass jar and tin can during storage up to 12 months at $30^{\circ} \mathrm{C}$.

Modha (2016) ${ }^{[5]}$ observed that total HMF content of readyto-reconstitute kheer mix packed in laminates of metallized pet-polyester/polyfilm pouches increased from 50.59 to $330.76 \mu$ moles $/ 100 \mathrm{~g}$ at the end of storage period of 6 months at $37^{\circ} \mathrm{C}$

Salooja (1983) ${ }^{[7]}$ reported increase in TBA value (absorbance 
units) from 0.010 to $0.073,0.057,0.050,0.040,0.037$ and 0.030 respectively for the powder packed in LDPE, METP, PP/LDPE/METP/LDPE, PP/AL/LDPE, glass jar and tin can during storage up to 12 months at $30{ }^{\circ} \mathrm{C}$

Kumar (1983) ${ }^{[3]}$ reported increase in TBA value of fresh sample of chocolate powder made from buffalo milk packed in polyethylene bags from 0.0 to 0.053 during the storage period of 12 months at $37^{\circ} \mathrm{C}$.

Modha (2016) [5] observed that TBA value of ready-toreconstitute kheer mix packed in laminates of metallized petpolyester/polyfilm increased from 0.652 to 1.034 at the end of storage period of 6 months at $37^{\circ} \mathrm{C}$.

Changes in the Microbial count of Oat and Milk Protein Concentrate Based Malted Milk Food during Storage

The standard plate count $\left(\log _{10} \mathrm{cfu} / \mathrm{g}\right)$ of control and oats and milk protein concentrate based malted milk food decreased with increase in storage period. SPC of $\mathrm{T}_{1}$ and $\mathrm{T}_{2}$ decreased from 4.17 and 4.30 to 2.78 and 3.10 respectively at the end of 180 days of storage at $37 \pm 2{ }^{\circ} \mathrm{C}$. The changes in the SPC count among the treatments $T_{1}$ and $T_{2}$ and the interaction effect between the treatments ( $\mathrm{T} 1$ and $\mathrm{T} 2$ ) and periods were nonsignificant $(\mathrm{P}>0.05)$. The coliform and yeast and mold count was not detected in both $T_{1}$ and $T_{2}$ throughout the storage period as water activity of the stored samples does not favour growth of yeast and mold.

Kumar (1983) ${ }^{[3]}$ reported decrease in standard plate count (cfu/g) of chocolate powder made from buffalo milk packed in polyethylene bags from 28,500 to $2,500 \mathrm{cfu} / \mathrm{g}$ during storage period up to 12 months at $37{ }^{\circ} \mathrm{C}$.

Table 1: Changes in the functional properties of oats and milk protein concentrate based malted milk food during storage

\begin{tabular}{|c|c|c|c|c|c|c|c|c|c|c|c|c|c|c|}
\hline \multirow{3}{*}{$\begin{array}{c}\text { Milk-cereal based } \\
\text { product }\end{array}$} & \multicolumn{13}{|c|}{ Storage period (days) } & \multirow{2}{*}{$\begin{array}{l}\text { Average of } \\
\text { treatments }\end{array}$} \\
\hline & $\mathbf{0}$ & 15 & 30 & 45 & 60 & 75 & 90 & 105 & 120 & 135 & 150 & 165 & 180 & \\
\hline & \multicolumn{13}{|c|}{ Poured density $\left(\mathrm{g} / \mathrm{cm}^{3}\right)$} & \\
\hline $\mathrm{T}_{1}$ & 0.483 & 0.563 & 0.565 & 0.566 & 0.565 & 0.575 & 0.575 & 0.584 & 0.588 & 0.593 & 0.611 & 0.619 & 0.625 & 0.577 \\
\hline $\mathrm{T}_{2}$ & 0.356 & 0.355 & 0.362 & 0.363 & 0.367 & 0.368 & 0.373 & 0.381 & 0.384 & 0.388 & 0.395 & 0.397 & 0.416 & 0.377 \\
\hline Average of periods & 0.420 & 0.459 & 0.464 & 0.464 & 0.466 & 0.471 & 0.474 & 0.482 & 0.486 & 0.490 & 0.503 & 0.508 & 0.520 & \\
\hline \multicolumn{15}{|c|}{$\mathrm{CD}(0.05) \mathrm{T}=0.001 ; \mathrm{P}=0.003 ; \mathrm{T} \times \mathrm{P}=0.004 ; \mathrm{CV} \%=0.59$} \\
\hline \multicolumn{15}{|c|}{ Loose density $\left(\mathrm{g} / \mathrm{cm}^{3}\right)$} \\
\hline $\mathrm{T}_{1}$ & 0.649 & 0.673 & 0.677 & 0.682 & 0.684 & 0.685 & 0.685 & 0.688 & 0.691 & 0.724 & 0.735 & 0.746 & 0.780 & 0.700 \\
\hline $\mathrm{T}_{2}$ & 0.455 & 0.456 & 0.461 & 0.462 & 0.463 & 0.467 & 0.468 & 0.471 & 0.475 & 0.482 & 0.487 & 0.491 & 0.493 & 0.472 \\
\hline Average of periods & 0.552 & 0.565 & 0.569 & 0.572 & 0.563 & 0.576 & 0.577 & 0.579 & 0.583 & 0.603 & 0.611 & 0.618 & 0.635 & \\
\hline \multicolumn{15}{|c|}{$\mathrm{CD}(0.05) \mathrm{T}=0.003 ; \mathrm{P}=0.006 ; \mathrm{T} \times \mathrm{P}=0.009 ; \mathrm{CV} \%=0.94$} \\
\hline \multicolumn{15}{|c|}{ Powder density $\left(\mathrm{g} / \mathrm{cm}^{3}\right)$} \\
\hline $\mathrm{T}_{1}$ & 0.720 & 0.722 & 0.724 & 0.732 & 0.731 & 0.733 & 0.734 & 0.734 & 0.745 & 0.755 & 0.767 & 0.771 & 0.781 & 0.742 \\
\hline $\mathrm{T}_{2}$ & 0.537 & 0.546 & 0.548 & 0.554 & 0.558 & 0.560 & 0.571 & 0.573 & 0.576 & 0.580 & 0.587 & 0.587 & 0.589 & 0.566 \\
\hline Average of periods & 0.629 & 0.634 & 0.636 & 0.643 & 0.644 & 0.647 & 0.652 & 0.654 & 0.623 & 0.667 & 0.677 & 0.679 & 0.684 & \\
\hline \multicolumn{15}{|c|}{$\mathrm{CD}(0.05) \mathrm{T}=0.011 ; \mathrm{P}=0.027 ; \mathrm{T} \times \mathrm{P}=\mathrm{NS} ; \mathrm{CV} \%=3.63$} \\
\hline \multicolumn{15}{|c|}{ Particle density $\left(\mathrm{g} / \mathrm{cm}^{3}\right)$} \\
\hline $\mathrm{T}_{1}$ & 1.20 & 1.15 & 1.15 & 1.16 & 1.17 & 1.17 & 1.18 & 1.19 & 1.20 & 1.21 & 1.28 & 1.22 & 1.23 & 1.19 \\
\hline $\mathrm{T}_{2}$ & 1.25 & 1.26 & 1.27 & 1.28 & 1.29 & 1.29 & 1.30 & 1.31 & 1.33 & 1.34 & 1.35 & 1.35 & 1.36 & 1.31 \\
\hline Average of periods & 1.23 & 1.20 & 1.21 & 1.22 & 1.23 & 1.23 & 1.24 & 1.25 & 1.26 & 1.27 & 1.28 & 1.29 & 1.29 & \\
\hline \multicolumn{15}{|c|}{$\mathrm{CD}(0.05) \mathrm{T}=0.011 ; \mathrm{P}=0.028 ; \mathrm{T} \times \mathrm{P}=\mathrm{NS} ; \mathrm{CV} \%=1.94$} \\
\hline \multicolumn{15}{|c|}{ Flowability (sec) } \\
\hline $\mathrm{T}_{1}$ & 68.20 & 68.67 & 68.75 & 69.70 & 71.37 & 72.01 & 74.41 & 75.17 & 75.50 & 76.64 & 77.20 & 77.96 & 79.76 & 73.48 \\
\hline $\mathrm{T}_{2}$ & 81.10 & 81.33 & 81.83 & 82.84 & 84.17 & 84.34 & 84.71 & 85.35 & 85.74 & 86.21 & 88.69 & 89.13 & 89.75 & 85.01 \\
\hline Average of periods & 74.65 & 75.00 & 75.29 & 76.27 & 77.77 & 78.18 & 79.56 & 80.26 & 80.62 & 81.43 & 82.95 & 83.54 & 84.76 & \\
\hline \multicolumn{15}{|c|}{$\mathrm{CD}(0.05) \mathrm{T}=0.102 ; \mathrm{P}=0.249 ; \mathrm{T} \times \mathrm{P}=0.352 ; \mathrm{CV} \%=0.27$} \\
\hline \multicolumn{15}{|c|}{ Solubility index (ml) } \\
\hline $\mathrm{T}_{1}$ & 1.19 & 1.95 & 1.98 & 2.00 & 2.300 & 2.71 & 2.92 & 3.18 & 3.37 & 3.43 & 3.54 & 3.57 & 3.60 & 2.75 \\
\hline $\mathrm{T}_{2}$ & 13.63 & 13.48 & 13.71 & 13.76 & 16.87 & 13.89 & 14.11 & 14.26 & 14.65 & 14.87 & 14.92 & 14.96 & 15.35 & 14.50 \\
\hline Average of periods & 7.74 & 7.71 & 7.84 & 7.88 & 8.08 & 8.30 & 8.52 & 8.72 & 9.01 & 9.15 & 9.23 & 9.26 & 9.48 & \\
\hline \multicolumn{15}{|c|}{$\mathrm{CD}(0.05) \mathrm{T}=0.022 ; \mathrm{P}=0.54 ; \mathrm{T} \times \mathrm{P}=0.076 ; \mathrm{CV} \%=0.55$} \\
\hline
\end{tabular}

Table 2: Changes in the sensory characteristics of oats and milk protein concentrate based malted milk food during storage

\begin{tabular}{|c|c|c|c|c|c|c|c|c|c|c|c|c|c|c|}
\hline \multirow{3}{*}{$\begin{array}{l}\text { Milk-cereal based } \\
\text { product (MCP) }\end{array}$} & \multicolumn{13}{|c|}{ Storage period (days) } & \multirow{3}{*}{$\begin{array}{l}\text { Average of } \\
\text { treatments }\end{array}$} \\
\hline & $\mathbf{0}$ & 15 & 30 & 45 & 60 & 75 & 90 & 105 & 120 & 135 & 150 & 165 & 180 & \\
\hline & \multicolumn{13}{|c|}{ Flavour score } & \\
\hline $\mathrm{T}_{1}$ & 8.41 & 8.25 & 8.00 & 7.34 & 7.58 & 7.52 & 7.35 & 7.29 & 7.08 & 7.05 & 6.73 & 6.14 & 5.66 & 7.26 \\
\hline $\mathrm{T}_{2}$ & 8.68 & 8.57 & 8.35 & 8.16 & 8.16 & 8.13 & 8.07 & 7.90 & 7.85 & 7.65 & 7.51 & 7.26 & 6.37 & 7.90 \\
\hline Average of periods & 8.54 & 8.41 & 8.17 & 7.95 & 7.87 & 7.82 & 7.71 & 7.60 & 7.46 & 7.35 & 7.12 & 6.70 & 6.02 & \\
\hline \multicolumn{15}{|c|}{$\mathrm{CD}(0.05) \mathrm{T}=0.019 ; \mathrm{P}=0.047 ; \mathrm{T} \times \mathrm{P}=0.067 ; \mathrm{CV} \%=0.53$} \\
\hline \multicolumn{15}{|c|}{ Appearance score of dry product } \\
\hline $\mathrm{T}_{1}$ & 8.08 & 7.93 & 7.82 & 7.72 & 7.66 & 7.47 & 7.37 & 7.37 & 7.24 & 7.17 & 6.76 & 6.05 & 5.64 & 7.25 \\
\hline $\mathrm{T}_{2}$ & 8.52 & 8.48 & 8.34 & 8.27 & 8.23 & 8.16 & 8.08 & 8.07 & 7.82 & 7.68 & 7.63 & 7.13 & 6.73 & 7.94 \\
\hline Average of periods & 8.30 & 8.21 & 8.08 & 8.00 & 7.95 & 7.82 & 7.73 & 7.72 & 7.53 & 7.42 & 7.20 & 6.59 & 6.19 & \\
\hline & & & & 05) $\mathrm{T}=$ & .010 & $=0.02$ & $5 ; \mathrm{T} \times \mathrm{P}$ & $=0.03$ & CV \% & 0.28 & & & & \\
\hline & & & & & . & 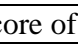 & 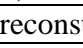 & ted & & & & & & \\
\hline
\end{tabular}




\begin{tabular}{|c|c|c|c|c|c|c|c|c|c|c|c|c|c|c|}
\hline $\mathrm{T}_{1}$ & 7.93 & 7.91 & 7.76 & 7.74 & 7.63 & 7.37 & 7.32 & 7.26 & 7.21 & 7.07 & 6.67 & 6.03 & 5.36 & 7.17 \\
\hline $\mathrm{T}_{2}$ & 8.29 & 8.22 & 8.19 & 8.07 & 8.01 & 7.95 & 7.95 & 7.79 & 7.67 & 7.34 & 7.26 & 7.23 & 6.56 & 7.73 \\
\hline Average of periods & 8.11 & 8.06 & 7.97 & 7.90 & 7.82 & 7.67 & 7.64 & 7.52 & 7.44 & 7.20 & 6.96 & 6.63 & 5.96 & \\
\hline \multicolumn{10}{|c|}{$\mathrm{CD}(0.05) \mathrm{T}=0.009 ; \mathrm{P}=0.022 ; \mathrm{T} \times \mathrm{P}=0.031 ; \mathrm{CV} \%=0.25$} \\
\hline \multicolumn{10}{|c|}{ Colour score } \\
\hline $\mathrm{T}_{1}$ & 8.08 & 7.84 & 7.75 & 7.71 & 7.56 & 7.55 & 7.52 & 7.48 & 7.33 & 7.21 & 7.16 & 6.90 & 6.51 & 7.43 \\
\hline $\mathrm{T}_{2}$ & 8.58 & 8.44 & 8.36 & 8.35 & 8.34 & 8.25 & 8.14 & 7.96 & 7.92 & 7.90 & 7.85 & 7.52 & 6.78 & 8.03 \\
\hline Average of periods & 8.33 & 8.14 & 8.05 & 8.03 & 7.95 & 7.90 & 7.83 & 7.72 & 7.63 & 7.55 & 7.51 & 7.21 & 6.65 & \\
\hline
\end{tabular}

Table 3: Changes in the physico-chemical properties of oats and milk protein concentrate based malted milk food during storage

\begin{tabular}{|c|c|c|c|c|c|c|c|c|c|c|c|c|c|c|}
\hline \multirow{3}{*}{$\begin{array}{c}\text { Milk-cereal } \\
\text { based product }\end{array}$} & \multicolumn{13}{|c|}{ Storage period (days) } & \multirow{3}{*}{$\begin{array}{l}\text { Average of } \\
\text { treatments }\end{array}$} \\
\hline & $\mathbf{0}$ & 15 & 30 & 45 & 60 & 75 & 90 & 105 & 120 & 135 & 150 & 165 & 180 & \\
\hline & \multicolumn{13}{|c|}{ Moisture (\%) } & \\
\hline $\mathrm{T}_{1}$ & 2.88 & 2.98 & 3.25 & 3.44 & 3.54 & 3.56 & 3.67 & 3.85 & 4.07 & 4.15 & 4.26 & 4.31 & 4.35 & 3.72 \\
\hline $\mathrm{T}_{2}$ & 2.10 & 2.11 & 2.19 & 2.26 & 2.33 & 2.44 & 2.56 & 3.16 & 3.84 & 3.90 & 3.93 & 4.96 & 4.03 & 3.06 \\
\hline $\begin{array}{c}\text { Average of } \\
\text { periods }\end{array}$ & 2.49 & 2.55 & 2.72 & 2.85 & 2.93 & 3.00 & 3.11 & 3.50 & 3.96 & 4.03 & 4.10 & 4.63 & 4.13 & \\
\hline \multicolumn{15}{|c|}{$\mathrm{CD}(0.05) \mathrm{T}=0.012 ; \mathrm{P}=0.029 ; \mathrm{T} \times \mathrm{P}=0.042 ; \mathrm{CV} \%=0.24$} \\
\hline \multicolumn{15}{|c|}{ Water activity } \\
\hline $\mathrm{T}_{1}$ & 0.285 & 0.285 & 0.288 & 0.289 & 0.290 & 0.291 & 0.291 & 0.292 & 0.293 & 0.293 & 0.296 & 0.296 & 0.306 & 0.292 \\
\hline $\mathrm{T}_{2}$ & 0.292 & 0.293 & 0.295 & 0.296 & 0.298 & 0.299 & 0.300 & 0.301 & 0.302 & 0.305 & 0.313 & 0.314 & 0.316 & 0.302 \\
\hline $\begin{array}{c}\text { Average of } \\
\text { periods }\end{array}$ & 0.289 & 0.289 & 0.292 & 0.293 & 0.294 & 0.295 & 0.296 & 0.297 & 0.297 & 0.299 & 0.305 & 0.305 & 0.311 & \\
\hline \multicolumn{15}{|c|}{$\mathrm{CD}(0.05) \mathrm{T}=0.001 ; \mathrm{P}=0.002 ; \mathrm{T} \times \mathrm{P}=0.002 ; \mathrm{CV} \%=0.49$} \\
\hline \multicolumn{15}{|c|}{ Free fatty acid (\% Oleic Acid) } \\
\hline $\mathrm{T}_{1}$ & 0.17 & 0.19 & 0.53 & 0.59 & 0.78 & 0.87 & 0.87 & 0.88 & 0.91 & 0.92 & 1.71 & 1.83 & 1.92 & 0.94 \\
\hline $\mathrm{T}_{2}$ & 0.22 & 0.28 & 0.31 & 0.49 & 0.62 & 0.62 & 0.76 & 0.77 & 0.84 & 0.95 & 1.13 & 1.16 & 1.18 & 0.72 \\
\hline $\begin{array}{c}\text { Average of } \\
\text { periods }\end{array}$ & 0.20 & 0.23 & 0.42 & 0.54 & 0.70 & 0.74 & 0.81 & 0.83 & 0.87 & 0.93 & 1.42 & 1.49 & 1.55 & \\
\hline \multicolumn{15}{|c|}{$\mathrm{CD}(0.05) \mathrm{T}=0.003 ; \mathrm{P}=0.007 ; \mathrm{T} \times \mathrm{P}=0.010 ; \mathrm{CV} \%=0.81$} \\
\hline \multicolumn{15}{|c|}{ Total HMF $(\mu$ moles/100g) } \\
\hline $\mathrm{T}_{1}$ & 49.57 & 58.33 & 75.47 & 81.32 & 81.47 & 105.13 & 139.59 & 165.35 & 184.31 & 208.23 & 227.42 & 245.48 & 294.29 & 147.38 \\
\hline $\mathrm{T}_{2}$ & 81.60 & 94.44 & 105.58 & 113.33 & 126.34 & 127.04 & 183.32 & 203.78 & 253.59 & 306.50 & 371.37 & 388.16 & 403.15 & 212.17 \\
\hline $\begin{array}{c}\text { Average of } \\
\text { periods }\end{array}$ & 65.59 & 76.39 & 90.54 & 97.32 & 103.91 & 116.08 & 161.45 & 184.56 & 218.95 & 257.36 & 299.40 & 316.82 & 348.71 & \\
\hline \multicolumn{15}{|c|}{$\mathrm{CD}(0.05) \mathrm{T}=0.103 ; \mathrm{P}=0.252 ; \mathrm{T} \times \mathrm{P}=0.356 ; \mathrm{CV} \%=0.13$} \\
\hline \multicolumn{15}{|c|}{ TBA value (OD at 532nm) } \\
\hline $\mathrm{T}_{1}$ & 0.95 & 0.98 & 1.14 & 1.16 & 1.19 & 1.28 & 1.32 & 1.43 & 1.43 & 1.53 & 1.95 & 1.98 & 2.29 & 1.44 \\
\hline $\mathrm{T}_{2}$ & 1.18 & 1.24 & 1.26 & 1.27 & 1.28 & 1.38 & 1.49 & 1.53 & 1.54 & 1.54 & 1.81 & 1.85 & 1.87 & 1.48 \\
\hline $\begin{array}{l}\text { Average of } \\
\text { periods }\end{array}$ & 1.07 & 1.11 & 1.20 & 1.22 & 1.24 & 1.24 & 1.41 & 1.48 & 1.49 & 1.55 & 1.88 & 1.92 & 2.08 & \\
\hline \multicolumn{15}{|c|}{$\mathrm{CD}(0.05) \mathrm{T}=\mathrm{NS} ; \mathrm{P}=0.139 ; \mathrm{T} \times \mathrm{P}=0.197 ; \mathrm{CV} \%=8.55$} \\
\hline
\end{tabular}

Table 4: Changes in the microbial count of oats and milk protein concentrate based malted milk food during storage

\begin{tabular}{|c|c|c|c|c|c|c|c|c|c|c|c|c|c|c|}
\hline \multirow{3}{*}{$\begin{array}{l}\text { Milk-cereal based } \\
\text { product }\end{array}$} & \multicolumn{13}{|c|}{ Storage period (days) } & \multirow{3}{*}{$\begin{array}{l}\text { Average of } \\
\text { treatments }\end{array}$} \\
\hline & $\mathbf{0}$ & 15 & 30 & 45 & 60 & 75 & 90 & 105 & 120 & 135 & 150 & 165 & 180 & \\
\hline & \multicolumn{13}{|c|}{ Standard plate count $\left(\log _{10} \mathrm{cfu} / \mathrm{g}\right)$} & \\
\hline $\mathrm{T}_{1}$ & 4.17 & 4.07 & 4.03 & 3.95 & 3.88 & 3.47 & 3.40 & 3.38 & 3.21 & 3.16 & 3.13 & 2.97 & 2.78 & 3.51 \\
\hline $\mathrm{T}_{2}$ & 4.30 & 3.96 & 3.91 & 3.68 & 3.56 & 3.54 & 3.48 & 3.30 & 3.24 & 3.17 & 3.13 & 3.12 & 3.10 & 3.50 \\
\hline Average of periods & 4.24 & 4.02 & 3.97 & 3.82 & 3.72 & 3.51 & 3.44 & 3.34 & 3.22 & 3.16 & 3.13 & 3.04 & 2.84 & \\
\hline \multicolumn{15}{|c|}{$\mathrm{CD}(0.05) \mathrm{T}=0.013 ; \mathrm{P}=0.032 ; \mathrm{T} \times \mathrm{P}=0.045 ; \mathrm{CV} \%=0.77$} \\
\hline
\end{tabular}

\section{Conclusion}

The oats and milk protein concentrate based malted milk food and control sample were stored at room temperature $\left(37 \pm 2^{\circ} \mathrm{C}\right)$ after packaging in laminates of metallized PET Polyester/ Polyfilm pouches. All the sensory parameters viz. flavour, appearance of dry and reconstituted product and colour scores decreased significantly over a period of 180 days of storage.
Decline in solubility index which reached the limit of $15 \mathrm{ml}$ as prescribed by FSSAI at the end of 180 days hence shelf life study was discontinued at the end of 180 days. So it is concluded that oats and milk protein concentrate based malted milk food packaged in laminates of metallized PETPolyester/Polyfilm pouches $(85 \mu \mathrm{m}$ thickness $)$ is acceptable up to 180 days of storage at $37 \pm 2{ }^{\circ} \mathrm{C}$. 


\section{References}

1. Agarwal S, Beausire R, Patel S, Patel H. Innovative uses of milk protein concentrates in product development. Journal of Food Science. 2015; 80(1):23-29.

2. Banerjee B, Ladkani BG. Physico-chemical properties of spray malted milk powder. Asian Journal of Dairy Research. 1985; 4(4):189-192.

3. Kumar A. Technological aspects of manufacturing of chocolate milk powder from buffalo milk. (Doctoral thesis, National Dairy Research Institute, Deemed University, Karnal, India), 1983.

4. Lockhart HB, Hurt DH. Nutrition of oats. In F. H. Webster (Ed.) Oats: Chemistry and Technology. American Association of Cereal Chemists, USA, 1986, 297-308.

5. Modha HM. Process optimization for manufacture of ready-to-reconstitute kheer. (Doctoral Thesis, Anand Agricultural University, Anand, India), 2016.

6. Potty VH. Oats-The small cereal with big heart. Indian Food Industry. 2006; 25:30-31.

7. Salooja M. Studies on the development of spray dried malted milk food. (Doctoral thesis, National Dairy Research Institute, Deemed University, Karnal, India), 1983.

8. Shah RK, Prajapati JB, Dave JM. Packaging materials to store spray-dried acidophilus malt preparation. Indian Journal of Dairy Science. 1987; 40(2):5-10. 